\title{
Comparative economic analysis of tomato (Lycopersicon esculenta) under irrigation and rainfed systems in selected local government areas of Kogi and Benue States, Nigeria
}

\author{
Josephine Bosede Ayoola \\ Institute of Food Security, University of Agriculture, Makurdi, P. M. B. 2373, Makurdi, Benue State, Nigeria.
}

Received 31 March, 2014; Accepted 19 August, 2014

\begin{abstract}
The study compared the economic performance of tomato (Lycopersicon esculenta) under irrigation and rain fed systems in Bassa and Makurdi Local Government Areas of Kogi and Benue States of Nigeria, with the aim of assessing the determinants of its profitability. Primary data obtained from a sample of $\mathbf{1 2 0}$ farmers by stratified and multi-staged random sampling from four villages were analyzed using percentages, means, gross margin, net profit, Shepherd-future coefficient and exponential regression model of combined profit function. Results revealed gender inequality; all respondents under irrigation system were male, compared to $71.7 \%$ female participation under rain fed system. Average net profits were $\mathrm{A} 128,750$ and $\mathrm{A} 57,050$; and economic efficiencies were 1.380 and 0.986 for irrigated and rain-fed systems respectively. Results also showed that farm size, planting material and herbicide were significant at one and five percent levels, and positively correlated with farmers' profit; while age and costs of fertilizer and labor were negative. The study concludes that tomato is more profitable and economically efficient under irrigation; and that increased access to land, herbicides, and improved seeds will promote profitability of the crop in the study area.
\end{abstract}

Key words: Irrigation, rain-fed, tomato (Lycopersicon esculenta), profitability, economic efficiency.

\section{INTRODUCTION}

Tomato (Lycopersicon esculenta) is an important vegetable crop grown in many parts of the world, contributing significantly to income security and the nutritive diets of many households. According to Mofeke et al. (2003) vegetable crops constitute 30 to $50 \%$ of iron and vitamin $A$ in resource poor diet. Vegetable crops including tomatoes are widely cultivated in most parts of Sub Sahara Africa, particularly by small scale farmers in most states of Nigeria (Adeolu and Taiwo 2009; Giroh et al., 2010). Global production of fruits and vegetables tripled from 396 million MT in 1961 to 1.34 billion MT in 2003 (International Institute of Tropical Agriculture, 2005) and Nigeria ranked $16^{\text {th }}$ on the global tomato production scale, accounting for $10.79 \%$ of Africa's and $1.2 \%$ of total world production of tomatoes (Weinberger and Lumpkin, 2007). 
Denton and Swarup (1983) observed that tomato production in the Northern States as in other parts of the country is done during the dry season, while its production is scarce during the rainy season because of high disease incidence associated with growing tomatoes and preference of tomato producers for grain food crops during rainy season. Nigeria is unable to meet its growing domestic requirements for vegetables, fruits, floriculture, herbs and spices, dried nuts and pulses. Between 2009 and 2010, Nigeria imported a total of 105,000 metric tons of tomato paste valued at over 16 billion Naira to bridge the deficit gap between supply and demand in the country (Food and Agriculture Organization, 2006). Kalu (2013) attributed this situation to socio-economic constraints surrounding the key actors in the tomato value chain, institutional weaknesses and declining agricultural research.

Irrigation farming relatively low in Nigeria and Africa as a whole, with irrigated area estimated at only $6 \%$ of total cultivated area, compared with $37 \%$ for Asia and $14 \%$ for Latin America (FAOSTAT, 2009). Svendsen and Sangi (2009) observed that more than two-third of existing irrigated area is concentrated in five countries namely Egypt, Madagascar, Morocco, Aouth Africa and Sudan. Given that irrigated crop yields are more than double of rainfed yields in Africa (Liangzhi et al., 2010), it is important to invest on irrigation development with particular focus on locations and technologies with greatest potential for irrigation. The efforts of the Federal Government of Nigeria, with the support of the World Bank and the African Development Fund to develop irrigation systems in the country started with the approval of the implementation of the National Fadama Development Project in 1992 (World Bank, 1992), followed by second National Fadama Development Project between 2004 and 2010, and the on-going third National Fadama Development Project (2008-2016). Small scale irrigation systems have gone a long way to support dry season farming of crops all over the country. Dry season production of vegetables is common along the banks of the rivers Niger and Benue that cut across cities and towns in Kogi and Benue States, respectively.

Tomato crop is cultivated in traditional small holdings in Nigeria and specifically in the study area. Denton and Swarup (1983), observed that tomato had ceased to be the main crop during rainy season in Northern Nigeria. In cognizance of the characteristic competition among major food crops for the limited resources of the farmers, one then wonders if the capital investment on irrigation for dry season farming of tomato is worthwhile relative to rainy season production; and what factors could further promote the profitability of tomato under irrigation or rain-fed system? Within this context, the general objective of the study was to assess the relative performance of tomato crop under irrigation and rain-fed systems in Bassa and Makurdi Local Government Areas of Kogi and Benue States of Nigeria respectively. Specifically, the study assessed the relative profitability and economic efficiency of tomato crop under irrigation and rain-fed systems, and identified the determinants of its profitability in the study area. It was thus, hypothesized that production of tomato crop under irrigation was not more economically efficient and profitable than those grown under rain-fed system; and that the socio-economic characteristics of the farmers did not affect profitable production in the area. It is expected that the results of the study would contribute to agricultural transformation policies and promote food security in Nigeria.

\section{CONCEPTUAL AND ANALYTICAL FRAMEWORK}

The conceptual framework is within the context of relative efficiency and profitability of investments in the production of tomato under irrigation and rain-fed systems. Thus, the concepts of gross margin and net profit were employed to compare the profitability, while Shepherd-future model was used to compare the economic efficiency of tomato crop under irrigation and rain-fed systems. Gross margin was measured in terms of the amount in Naira that is contributed to the enterprise after paying for direct variable unit costs, while the net profit accounts for the direct fixed costs in addition. The total variable costs comprised the expenses incurred on variable inputs such as fertilizers, seeds, and labor; while fixed costs comprised expenses on rent on land, depreciation of capital assets such as irrigation pumps, hoes, cutlasses, and wheel barrow. Shepherd-future coefficient was used as a measure of how well each naira return on the enterprise is utilized to cover the operational and overhead expenses. Shepherd-future model was expressed as the ratio of gross margin obtained from the production of tomato crop to the total cost of production (Shepherd, 1962). Greater positive net profit and Sheperd-futre coefficient would indicate higher profitability and efficiency of tomato crop production.

\section{METHODOLOGY}

\section{Study area}

The study was carried out in North Central Nigeria, covering Sharia and Gboloko villages in Bassa LGA of Kogi State, and Ugondo and Mbayong villages in Makurdi LGA of Benue State, where Fadama land is very prominent. The area is located in Southern Guinea Savanna zone within latitude $14^{\circ} \mathrm{N}$ and $16^{\circ} \mathrm{N}$ and longitude $12^{\circ} \mathrm{E}$ and $13^{\circ} \mathrm{E}$, respectively for Kogi and Benue States; with annual rainfall of between 1100 and $1600 \mathrm{~mm}$ and an average temperature of $35^{\circ} \mathrm{C}$ (National Population Commission, NPC 2006). Both states are bound on the North and West by Rivers Niger and Benue.

\section{Data sampling and collection methods}

A total sample of 120 farmers used for the study was selected using stratified and six-staged random techniques. The sample was 
stratified into two; 60 farmers under one rrigation system and 60 farmers under rain-fed system. The six-stage random sampling firstly comprised, of the two States (Kogi and Benue) randomly selected from among six States in the Southern Guinea agroecological zone (Kwara, Niger, Benue, Kogi, Nasarawa and Taraba States). Secondly, one Local Government Area (LGA) was selected from each State (Bassa LGA from Kogi state and Makurdi LGA from Benue state). Thirdly, two villages were selected in each LGA (including Sharia and Gboloko in Bassa LGA of Kogi State, and Udongo and Mbayong in Makurdi LGA of Benue State). Fourthly, 3 Fadama Associations (FAs) were selected in each of the four villages making $12 \mathrm{FAs}$; and fifthly, 5 farmers were randomly selected from each of the FAs making a total of 60 farmers (15 farmers per village) under irrigation system. Lastly, 15 farmers that cultivated tomato crop under rain-fed system were purposively selected from each of the four villages to make a total of 60 farmers under rain-fed system.

Structured questionnaire was used to obtain primary data about farmers' socio-economic characteristics; such as sex (male or female), family size (number of persons in the household), age (years), and educational level (number of years in school). Also, data were obtained on production variables such as farm size (ha), farm output ( $\$$ ); variable costs ( $\$$ ) such as costs of fertilizer, labour, planting materials, pesticide and herbicide; and fixed costs ( $\$$ ) such as rent on land, as well as depreciation of capital assets such as irrigation pumps, hoes, cutlasses, and wheel barrow.

\section{Analytical methods}

Descriptive and inferential statistics including frequency, percentage, gross margin and net profit analyses were used to describe the socio-economic characteristics of farmers and level of profitability of tomato crop production. Multiple regression was also used to analyze the socio-economic determinants and coefficients of profitability, while Shepherd-future coefficient was used to determine the economic efficiency of tomato crop under irrigation and rain-fed systems.

\section{Models specification}

(1) The functional form of the multiple regression function is:

$Y=\beta 0+\beta_{1} X_{1}+\beta_{2} X_{2}+\beta_{3} X_{3}+\beta_{4} X_{4}+\beta_{5} X_{5}+\beta_{6} X_{6}+e_{1}$

Where: $Y=$ Profit $(\mathbb{A}) ;$ Bo $=$ Intercept $(\mathbb{A}) ; \beta=$ Marginal effect of $X s$ on $\mathrm{Y} ; \mathrm{X}_{1}=$ Farm size (ha); $\mathrm{X}_{2}=$ Educational level (number of years in school); $X_{3}=$ Age of the farmer (years); $X_{4}=$ Cost of fertilizer $(\mathrm{N})$; $X_{5}=$ Cost of labour $(\mathbb{N}) ; X_{6}=$ Cost of planting materials $(\mathrm{N}) ; X_{7}=$ Cost of herbicide $(\mathbb{N}) ; e_{1}=$ Error term,

(2) Gross Margin: GM = TR - TVC; where GM = Gross Margin ( $\mathrm{N}$ ); TR = Total Revenue (A); TVC = Total Variable Cost ( $\mathrm{A})$,

(3) Net Profit: NP = TR - TC; where: NP = Net Profit (N); TR = Total Revenue $(\#) ;$ TC $=$ Total Cost $(\#)=$ Total Variable Cost $($ TVC) + Total Fixed Cost (TFC),

(4) Shepherd-future: S.F = $($ GMTC $) \times 100$; Where: S.F. = Shepherd-future.

\section{RESULTS AND DISCUSSION}

\section{Socio-economic characteristics of tomato farmers}

The results revealed that all the farmers under irrigation $\mathrm{s}$ ystem were male while about $72 \%$ of farmers under rain- fed system were female farmers (Table 1); indicating gender inequality in access of farmers to irrigation facilities, and insensitivity of the irrigation programme to the Millennium Development Goal of gender equality and women empowerment (United Nations Development Programme, 2002, and International Food Policy Research Institute, 2006). About $62 \%$ of farmers under irrigation system and $22 \%$ of farmers under rain-fed system were above 50 years of age; indicating that majority of the farmers were getting advanced in age and may lack sufficient vigor for large scale and efficient production of vegetable crops. About $73 \%$ of farmers under irrigation system and $68 \%$ of farmers under rainfed system have no formal education; indicating that low literacy rate among the farmers might hinder adoption of innovations since education has been reported to influence the level of technology adoption (Chinaka et al., 1995).

Despite the family size that was above six for about $94 \%$ of the farmers, more than $80 \%$ of farmers under irrigation system employed hired labor for farm operations; indicating that family labor was not a preferred option for reducing the cost of labor. About $98 \%$ of farmers under irrigation system have more than 10 years of farming experience; suggesting the possession of necessary farming and irrigation skills for increased productivity and efficiency. About $53 \%$ of farmers under irrigation system were land owners while about $47 \%$ obtained their farm land on lease from government; land ownership structure might be a decision factor with respect to investment on irrigation facilities as farmers that owned land could guarantee continuous access to the use of irrigated land. Majority of the farmers $(58 \%$ under irrigation system and $98.4 \%$ under rain-fed system) cultivated less than 2 ha of farm size; indicating that tomato crop farming is generally small scale and corroborating Kalu (2013) that tomato is produced on small holdings in Northern Nigeria.

\section{Relative profitability and economic efficiency of tomato crop}

Table 2, results showed that gross margins obtained per hectare of tomato crop under irrigation and rain-fed systems were $\$ 153,500$ and $\$ 68,000$, respectively; and average net profits per hectare were $\$ 128,750$ and A57,050. Shepherd-future coefficients were 1.380 and $0.986 \mathrm{t}$, indicating that tomato crop was economically efficient under both irrigation and rain-fed systems. The results indicated that investment on tomato crop production under irrigation system was worthwhile, as it yielded greater revenue in excess of operational and overhead expenses in comparison with that of rain-fed system. These results corroborate Hussain and Wijerathna (2004) linking irrigation and poverty alleviation in developing countries. Adewumi et al. (2005) that 
Table 1. Socio-economic characteristics of farmers under irrigation and rain-fed systems.

\begin{tabular}{ccccccc}
\hline \multirow{2}{*}{ Socio-economic variables } & \multicolumn{2}{c}{ Irrigation system } & \multicolumn{2}{c}{ Rain-fed system } & \multicolumn{2}{c}{ Total } \\
\cline { 2 - 7 } & Frequency & $\%$ & Frequency & $\%$ & Frequency & $\%$ \\
\hline Sex: Male & 60 & 100 & 17 & 28.3 & 77 & 64.17 \\
Female & - & - & 43 & 71.7 & 43 & 35.83 \\
Age (years): $<40$ & 9 & 15 & 21 & 35 & 30 & 25 \\
$41-50$ & 14 & 23.33 & 26 & 43.3 & 40 & 33.33 \\
$>50$ & 37 & 61.67 & 13 & 21.7 & 50 & 41.67 \\
Educational status: No formal & 44 & 73.3 & 37 & 61.7 & 81 & 67.5 \\
Primary (1-6 years) & 16 & 26.7 & 22 & 36.7 & 38 & 31.67 \\
Secondary (7-12 years) & - & - & 1 & 1.6 & 1 & 0.83 \\
Family size: $<6$ & 2 & 3.3 & 5 & 8.3 & 7 & 5.83 \\
6-10 & 32 & 53.3 & 34 & 56.7 & 66 & 55 \\
$>10$ & 26 & 43.4 & 21 & 35 & 47 & 39.17 \\
Farming experience (years): $<10$ & 1 & 1.7 & 30 & 50.0 & 31 & 25.83 \\
10-20 & 28 & 46.6 & 26 & 43.33 & 54 & 45.00 \\
$>20$ & 31 & 51.7 & 4 & 6.67 & 35 & 29.17 \\
Land status: Bought & 3 & 5.0 & 26 & 43.0 & 29 & 24.17 \\
Inheritance & 29 & 48.3 & 24 & 40.0 & 53 & 44.17 \\
Rent / Leased & 28 & 46.7 & 10 & 16.7 & 38 & 31.66 \\
Farm size (Ha): $<1$ & 2 & 3.1 & 34 & 56.7 & 36 & 30 \\
1<X<2 & 33 & 55.0 & 25 & 41.7 & 58 & 48.33 \\
$2-3$ & 23 & 38.4 & 1 & 1.6 & 24 & 20 \\
$>3$ & 2 & 3.3 & - & - & 2 & 1.67 \\
Hired & 6 & 10.0 & 41 & 68.3 & 47 & 39.17 \\
Both & 48 & 80.0 & 19 & 31.7 & 67 & 55.83 \\
\hline
\end{tabular}

tomato farming under small scale irrigation systems was profitable in Sokoto State; where an average gross margin of N87,543.00/ha and average net income of $\mathrm{N} 77,559.80 / \mathrm{ha}$, with a rate of return to investment greater than 1 were obtained. Denton and Swarup (1983) had earlier observed that tomato crop has ceased to be the main crop during the raining season in Northern States, because farmers sustained greater loss during the rainy season due to diseases, nematodes, insect pests and high flower drops; resulting in lower yield and poor quality fruits (Sabo and Dia, 2009). Kalu (2013) later observed that farmers in Northern Nigeria engaged in the production of other crops during raining seasons, while they planted tomatoes in the dry season using the irrigation system, as a strategy for reducing losses incurred on tomato farming. Gani and Omonona (2009) also confirmed greater profitability and economic efficiency for maize production under irrigation system relative to rain-fed system. These results indicated that investments in irrigation facilities for tomato crop production would promote higher income among small scale farmers, and thus contribute to poverty alleviation in the study areas. Similarly, irrigation agriculture has been linked to poverty reduction in six Asian Countries
(Hussain, 2007).

\section{Determinants of profitability of tomato production}

The exponential regression model of combined profit function gave the coefficient of multiple determination $\left(R^{2}\right)$ value of 0.91 (Table 3 ), implying that $91 \%$ of the variation in farmers' profit is explained by the independent variables while the remaining $9 \%$ could be accounted for by the error term. The parameter estimates of combined profit function for tomato crop showed that age and planting material as well as farm size and herbicide were significant at one percent and five percent respectively. Farm size, level of education, cost of herbicide and planting material have positive correlation with farmers' profit; while age and costs of fertilizer and labor were negatively correlated to farmers' profit. These results implied that an increase in farm size, level of education, planting material and cost of herbicide would lead to an increase in income from tomato. Formal education could aid managerial ability of farmers and enable them achieve greater efficiency in tomato crop production. Age of farmers was significantly negative; 
Table 2. Costs and Returns per hectare on tomato crop under irrigation and rain-fed systems.

\begin{tabular}{|c|c|c|c|c|c|c|c|}
\hline \multirow{2}{*}{ Cost and return } & \multirow{2}{*}{$\begin{array}{l}\text { Life span } \\
\text { (years) }\end{array}$} & \multirow{2}{*}{$\begin{array}{c}\text { Unit price } \\
(\mathbb{N})\end{array}$} & \multicolumn{2}{|c|}{ Irrigation system } & \multirow{2}{*}{$\begin{array}{c}\text { Unit } \\
\text { price (A) }\end{array}$} & \multicolumn{2}{|c|}{ Rain-fed system } \\
\hline & & & Quantity & Total cost $(\mathrm{N})$ & & Quantity & Total cost $(\mathrm{N})$ \\
\hline \multicolumn{8}{|l|}{ Fixed costs items } \\
\hline Cutlass & 2 & 1000 & 5 & $2,500^{*}$ & 1000 & 3 & $1500^{*}$ \\
\hline Irrigation equipment & 2 & 25000 & 1 & $12,500^{*}$ & & & \\
\hline Wheel barrow & 2 & 5000 & 2 & $5,000^{*}$ & 5000 & 2 & $5,000^{*}$ \\
\hline Land (rent) & - & & - & 4,000 & & & 4,000 \\
\hline Hoe & 6 & 900 & 5 & $750^{*}$ & 900 & 3 & $450^{*}$ \\
\hline Total fixed cost & & & & 24,750 & & & 10,950 \\
\hline \multicolumn{8}{|l|}{ Variable costs items } \\
\hline Labor (mandays/ha) & - & 1000 & 20 & 20,000 & 1000 & 10 & 10,000 \\
\hline Pesticide (litres/ha) & - & 1000 & 5 & 5,000 & 1000 & 2.5 & 2,500 \\
\hline Herbicide (litres/ha) & - & 1200 & 5 & 6,000 & 1200 & 5 & 6,000 \\
\hline Fertilizer (kg/ha) & - & 4500 & 4 & 18,000 & 4500 & 2 & 9,000 \\
\hline Seed (kg/ha) & - & 1500 & 15 & 22,500 & 1500 & 15 & 22,500 \\
\hline Transportation & - & & & 15,000 & & & 8,000 \\
\hline Total variable cost & & & & 86,500 & & & 58,000 \\
\hline Total production cost & & & & 111,250 & & & 68,950 \\
\hline Total Revenue & & 2000 & 120 & 240,000 & 1200 & 105 & 126,000 \\
\hline $\begin{array}{l}\text { Average Gross } \\
\text { Margin per ha }\end{array}$ & & & & 153,500 & & & 68,000 \\
\hline Average Net profit/ha & & & & 128,750 & & & 57,050 \\
\hline Economic Efficiency & & & & 1.380 & & & 0.986 \\
\hline
\end{tabular}

Note: Asterisked $\left({ }^{*}\right)$ figures are depreciated costs for the respective fixed capital items.

Table 3. Parameter estimates of exponential regression model of combined profit function for tomato production.

\begin{tabular}{lcccc}
\hline Variables & Coefficient & Standard error & t-value & p $>/$ t/ \\
\hline Farm size & 72105.89 & 29675.94 & 2.43 & $0.017^{* *}$ \\
Education & 3564.318 & 4589.122 & 0.78 & 0.439 \\
Age & -6951.96 & 1494.602 & -4.65 & $0.000^{\star * *}$ \\
Fertilizer & -0.9568392 & 0.6603224 & -1.45 & 0.150 \\
Labor & -0.2029115 & 1.674137 & -0.12 & 0.904 \\
Planting material & 3.411511 & 0.5859465 & -5.82 & $0.000^{* * *}$ \\
Herbicide & 5.885283 & 2.618464 & 2.25 & $0.027^{\star *}$ \\
Constant & 202212.5 & 77502.95 & 2.61 & 0.010 \\
\hline
\end{tabular}

Note: $R^{2}=0.91, F$-value $=126,{ }^{* *}=5 \%$ significance, ${ }^{* *}=1 \%$ significance.

implying that older farmers tend to be less efficient. The cost of fertilizer was also negatively correlated with farm income and was not significant; suggesting that achieving greater efficiency in fertilizer utilization would not likely lead to significant increase in profit obtained on tomato crop production. Result also showed that cost of labor was negative while cost of herbicide was positively correlated with profit; meaning that an increase in the amount spent on labor will lead to reduced profit while an increase in the level of herbicide cost will lead to increase in profit on tomato production. This suggests that substitution of herbicide for labor may reduce cost of weeding and thus, enhance profitability of tomato production. The cost of planting material was also positively correlated with profit and significant at one percent; indicating that more use of improved planting materials might enhance the profitability of tomato crop production. These results confirmed the findings of Ayanwale and Abiola (2008) that farm size, education level and capital inputs are critical determinants of efficiency of vegetable production under tropical conditions. 


\section{SUMMARY AND CONCLUSIONS}

The study aimed at assessing the extent to which investment in small scale irrigation have contributed to profitability of tomato crop farming in the North Central Southern Guinea Savanna agro-ecology of Nigeria. Specifically, the study estimated the relative profitability and efficiency of tomato crop production under irrigation and rain-fed systems, and identified the socio-economic determinants of profitability of tomato crop. Primary data obtained from a sample of 120 farmers were analyzed using descriptive statistics, gross margin, net profit, as well as Shepherd-future and multiple regression models.

Results showed that all the respondents under irrigation system were male farmers, indicating gender inequality in farmers' access to irrigation facilities. Majority of the farmers were above 50 years of age, with low literacy and average family size of 8 per household. Results also showed that the gross margins per hectare under irrigation and rain-fed systems were $\$ 153,500$ and N68,000 respectively; and that average net profits per hectare were $\$ 128,750$ and $A 57,050$; indicating profitability of tomato crop under both systems. Shepherd-future coefficients were 137.98 and $98.62 \%$ respectively for irrigation and rain-fed systems; indicating that tomato crop was more economically efficient under irrigation system than rain-fed system. Parameter estimates from the combined profit function also revealed that farm size, level of education, cost of herbicide and planting material have positive correlation; while age of farmers, costs of fertilizer and labor were negatively related to farmers' profit. Age of farmers and planting materials were significant at one percent, while farm size and costs of herbicide were significant at five percent.

Thus, it was concluded that tomato crop was more profitable and economically efficient under irrigation; and that increased access to land, herbicides, and improved seeds would promote profitability of the crop in Bassa and Makurdi Local Government Areas of Kogi and Benue States, Nigeria. Land policies that increase access of farmers (with special consideration for women farmers) to adequate land, irrigation facilities, herbicides and good quality improved planting material would promote gender equality in irrigation farming and profitability of tomato production; thus contributing to food security in Nigeria and enhancing the income potential of farmers.

\section{Conflict of interest}

The authors have not declared any conflict of interest.
Adeolu BA, Taiwo A (2009). Potential and Opportunities for Sustainable Production and Utilization of Horticultural Crops in Nigeria. Horticultural EOS magazine, September 2009. P. 9.

Ayanwale AB, Abiola MO (2008). Efficiency of Fluted Pumpkin Production under Tropical Conditions. Int. J. Veget. Sci. 13(3):35-49. http://dx.doi.org/10.1300/J512v13n03_04

Chinaka CC, Chikwendu DO, Asumughā GN (1995). A Socio-economic Study of the Adoption and Sustainability of Improved Cassava Varieties Among Resource Poor Farmers in South-East Zone of Nigeria. In Root crops and poverty alleviation. International Society for Tropical Crops African Branch, Malawi. pp. 333-336.

Denton T, Swarup V (1983). Tomato Cultivation and its Potential in Nigeria. Acta Hort. (ISHS) 123:257-272. http://www.actahort.org/books/123/123_23.htm)

Food and Agriculture Organization (2006). State of Food Insecurity in the World. Food and Agricultural Organization, FAO. Rome.

FAOSTAT (2009). Food and Agriculture Organization, FAO AQUASTAT: http://www.fao.org/nr/water/aquastat/dbase/index.sfm> Accessed May 2009.

Gani BS, Omonona BT (2009). Resource Use Efficiency Among Small Scale Irrigated Maize Producers in Northern Taraba State of Nigeria. J. Hum. Ecol. 28(2):113-119.

Giroh DY, Waizah Y, Umar HY (2010). Technical Efficiency and Cost of Production Among Gum Arabic Farmers in Jigawa State. Report Opin. 2(1):52-57.

Hussain I (2007). Irrigation and Poverty Alleviation: Pro-poor Intervention Strategies in Irrigated Agriculture in Asia. Paper presented in the $4^{\text {th }}$ Asian Regional conference and $10^{\text {th }}$ International Seminar on Participatory irrigation Management. 2-5 May, 2007, Tehran, Iran. http://fadama.org/taraba.html

Hussain I, Wijerathna D (2004). Irrigation and Income-poverty Alleviation: A comparative analysis of irrigation systems in developing Asia. International Water Management Institute (IWMI) February 2004.

International Food Policy research Institute (2006). Agriculture and Achieving the Millenium Development Goals. Agriculture and Rural development Department. Report No. 32729 GLB. Pp. 10

International Institute of Tropical Agriculture, IITA (2005). Annual Report 2005, IITA, Ibadan, Nigeria. pp. 29-30.

Kalu S (2013). The great tomato waste in Nigeria. http://kalusam.wordpress.com/2013/09/11

Liangzhi Y, Claudia R, Gerald N, Ulrike W-S, Richard R, Stanley W, Zhe G, Tingju Z, Yau S (2010). What is the Irrigation Potential for Africa? A combined Biophysical and Socio-economic Approach. IFPPRI Discussio Paper 00993. Environment and Production Technology Division. June 2010.

Mofeke ALE, Ahmada A, Mudiane OJ (2003). Relationship Between Yield and Seasonal Water Use for Tomatoes, Onions, and Potatoes Grown under Fadama Irrigation. Asset Series A. 3:35-46.

Sabo E, Dia YZ (2009). Awareness and Effectiveness of Vegetable Technology Information Packages by Vegetable Farmers in Adamawa State, Nigeria. Afr. J. Agric. Res. 4(2):065-070, February, 2009

Shepherd GS (1962). Marketing Farm Products Economic Analysis. $4^{\text {th }}$ Edition. Ames lowa, lowa State University Press.

Svendsen E, Sangi M (2009). Measuring Irrigation Performance in Africa: IFFPRI Discussion Paper 894, Washington D.C., IFFPRI

United Nations Development Programme (UNDP) (2002). Human Development Report 2002. Available at: www.undp.org/hdr2002/

Weinberger K, Lumpkin TA (2007). Diversification into Horticulture and poverty Reduction: A research agenda. World Dev. 35(8):1464-1480. http://dx.doi.org/10.1016/j.worlddev.2007.05.002

World Bank (1992). National Fadama Development Project (NFDP), Staff Appraisal Report (SAR). Washington D.C. World Bank, pp. 5572.

\section{REFERENCES}

Adewumi MO, Omotesho OA, Tsoho B (2005). Economics of irrigation farming in Nigeria: a case study of tomato based farming in Sokoto State, Nigeria. Int. J. Agric. Rural Dev. 6:103-110. 